\title{
Online Learning during Corona Virus 2019: Empirical Analysis
}

\author{
Muhammad Tariq Bhatti \\ Assistant Professor, \\ Shah Abdul Latif University, \\ Khairpur, Pakistan
}

DOI: https://doi.org/10.36941/mjss-2021-0053

\begin{abstract}
Corona Virus Disease (COVID-19) was declared a worldwide pandemic by the World Health Organization (WHO) on mid of March 2020. Globally, most governments - including Pakistan - approved extraordinary social control measures to stem the tide of this pandemic disease. These actions required social segregation and a temporary suspension of education. As with all other institutions of higher education, public and private universities will also be required to offer distance learning to students by the end of the academic year 2020-2021. Universities of private and public sector, at all levels of higher education, suspended physical classes and implemented online teaching for university students. And, this spontaneous, quick, and uncertain nature of the teaching created difficulties for students. Data on accepted procedures for directing such sudden transitions to university education were scarce, and there was no consensus on the best way to proceed. Students at public and private universities have been impacted by a shift to distance education. Studying students' academic difficulties and the unexpected benefits of distance education, and then using that information to develop strategies that could be used in emergency situations in university education, was the goal of the study.
\end{abstract}

Keywords: Online education, COVID-19, Distance education, University

\section{Introduction}

China's city of Wuhan is located in the province of Hubei. On December 31, 2019, Chinese officials reported multiple cases of an unclear pneumonia-like sickness masquerading as influenza to the World Health Organization (WHO). World Health Organization (2020), after infection detachment and examination of the viral genome grouping from lower respiratory tract samples of infected patients, identified and designated it as Coronavirus Disease-19 (COVID-19). The WHO declared Coronavirus-19 a universal pandemic a month after its beginning, and the infection was declared a public health emergency by the Government of Pakistan a day later (Zahra, 2020). By July 21, 2021, the WHO has confirmed 192.788 million Coronavirus diseases in more than 180 sectors i.e., public and private, with Pakistan accounting for 1.094 million of those cases (Asad, 2021; WorldoMeter, 2021, July 21). While attempting to limit the spread of Coronavirus, most governments around the world, including Pakistan, authorized significant social distancing due to the lack of a successful antibody doze or treatment.

Social distancing, temporary closure of education institutions, and distance learning, which are administered in higher education institutions including public and private universities, were among 
the strategies used during pandemic. Public and private universities and other educational institutions had no choice other than the implementation of online classes in traditional set up without preparation of the digitalized prerequisites achieved. This online education needs computer experts, computer hardware and other related devices, availability of the internet and software of users' application. However, the haphazard transition of distance education created a lot of problems and issues for university administration, students and faculty alike. Currently, nearly 2900 higher education institutions and universities in Pakistan have closed temporarily, affecting a large number of students (Zahra, 2020). Whilst distance education in Pakistan's public and private universities and other higher education institutions is certainly not a new plan and learning method, the unexpected, rapid and disruptive length of the distance education poses problems and adversely affects students at every level. The researcher aimed to explore on what type of challenges undergraduate, graduate, and postgraduate students face during COVID-19, enrolled in Pakistan's public and private universities. Furthermore, the researcher also investigated the impact of distance education on these students' taking courses in public and private universities. For this purpose, the relationship was analyzed between various independent and dependent variables, such as motivation to learn and complete the course and completion of assignments and other projects within time, teaching faculty routines, social and financial factors. In this way, the academic challenges of undergraduates, graduates, and postgraduates of public and private universities were analyzed and unforeseen benefits of distance education were explored that may be fitted the future university education in emergencies and calamities.

Distance education, also known as web-based education, distance learning, e-education, or online learning, is a kind of learning where faculty and students are fully isolated through education (Burns, 2020). It is a learning practice that successfully uses a variety of equipment and the internet, as well as work with student teaching faculty and correspondence (Elzainy 2020), in order to improve the student education (DevTrio, 2019). The acquisition of equipment such as a faculty computer, mobile device (cells), or webcam, some type of listening device, video conferencing applications such as WebEx or Zoom, Microsoft Team, Microsoft Windows or Apple working frameworks, and a steady web connection with a speed of around $56 \mathrm{~K}(56,000)$ or higher are the fundamental technological prerequisites for fruitful distance education ( $\mathrm{Li}, \mathrm{C} \&$ Lalani, f., 2020). Both public and private universities offer bachelor's, master's, and doctoral degree programs. Students' access to and quality of instruction were the most important priorities for universities during the turbulent academic session of 2020-2021, despite the challenges of meeting their diverse needs. Teaching faculty speaking in a classroom environment, students listening, taking notes, asking questions and having those questions answered has been at the core of traditional university instruction since the dawn of time (Naz et al., 2016). As communication the internet improves like the phone, radio, TV, and, most recently, the web, new means for learning have emerged, including distance education (Okeleke, K, 2019). The internet has made it possible for students to easily receive guidance and learn at home, as they can listen to an instructor thousands of miles away, interact with the educator, and solve problems without having to be present. As a learning strategy, distance learning has evolved from a "anywhere" to a "whenever" option in theory and in practice (Ramos et al., 2020).

However, it has now become an established part of university education as well as a possibility for some traditional students. Because of the social distancing, students have fewer options for choosing online courses, and there is a lack of motivation to learn. This is due to the new course academic tasks, job related issues, and a lack of motivation. For some students, distance education is difficult to implement. Online education will be difficult to replicate unless all students have equal access to these tools, the teaching faculty has adequate planning and preparation time, and existing educational programs are adapted or new course syllabuses are developed. The value of distance education has been questioned; for example, whether it helps undergraduates, graduates and postgraduates absorb knowledge the same way they would in a classroom? However, despite the importance of these questions, the university education system must also consider other important factors, such as how to assist students without reliable internet access or technology to participate in 
online learning. As a result of the disparity in access to the internet and technology, minorities are disproportionately impacted. Some universities have provided assistance to students in need of digital hardware, but many others have not. Individuals will be negatively impacted by the pandemic, universities are concerned.

Using LMS and faculty announcements, public and private universities informed their undergraduates, graduates, and postgraduates of their main study objectives. On one occasion, students who agreed to participate in the study were contacted and asked to complete an hour digital study using Likert scale questionnaire. By completing the survey, students consented to participate in the empirical study. Students were not asked to provide any identifying information about themselves or their faculty members. Data was collected daily using Qualtrics XM/ (The Main Experience the Board Software). Research was open to every student at the university.

Researcher has conducted a cross-sectional study of university students who have got access in undergraduate, graduate, and postgraduate programs of public or private university to explore their academic challenges because of coronavirus and how distance education was affecting their studies. Since not all universities, students or teaching faculty know about distant education and some students still don't have Wi-Fi access, and some of them have jobs, the study's purpose was (i) to explore the needs and challenges of students were facing during COVID-19, (ii) to inform management of public and private sector universities about these needs and chandlers of students so that they can address them and prepare advance properly, and (iii) investigate the various effects of distance education transition during corona-19. The survey focused on eight categories and contained 59 different open ended and closed ended statements, and Likert Scale items (ranging from "strongly disagree" to "strongly agree"). These eight categories consisted on: 1) web-based teaching style preferences, 2) academic tasks, 3) telecommunication access, 4) teaching faculty routines during COVID-19, 5) demographics, 6) motivation to learn, 7) social and financial factors, and 8) recommendations. The web-based teaching variable estimated whether students favored synchronous or asynchronous learning and the academic tasks variable estimated if academic tasks for student learning had been increased by the transition of their classes on the Internet and the kind of assessment students required. Telecommunication access variable analyzed the use of digital devices for the internet connectivity and participation in online classes, students' logging in habits and routines, access to the internet, availability of the internet and computers and how many hours in a day students use computers and the internet for study purpose. The fourth category, teaching faculty routines evaluated; a) availability of an adjusted and tailored syllabus by the faculty before commencements of the online classes, b) teaching faculty's presence and access to the students during office hours for queries regarding the online classes, c) the engaging way of faculty while conducting online classes, d) availability of recorded lectures of faculty, and d) faculty communication what with regard to online classes. The demographics variable explored the gender and academic status of the private and public university students. Similarly, motivation to learn evaluated: a) the students' ability to complete projects and assignment within time, b) to remember to login to online classes and quizzes, c) to communicate with other class fellows for class projects and assignments, and d) time management for online classes and tasks. The social and financial factors variable focused on: a) students' concerns about getting COVID-19, b) COVID-19 related concerns about family and close friends' infection of, c) the job related effects of COVID-19, if they could find job somewhere, d) financial security related concerns during the pandemic, finally, e) on the whole effects on their lives. Finally, recommendations gave students an opportunity to share their thoughts on the impact of distance education and what they would like to see the university do in order to improve its performance in this area.

\section{Analysis}

After the Qualtrics data had been cleansed, Splinter was used to analyze the results. In order to assess quantitative data, various analytical techniques were used. It was decided to exclude any quantitative data 
that wasn't available to us. Statistical Package for the Social Sciences version 26 was used for the quantitative analysis of the data. Coding and detailed descriptions were used to analyze the qualitative data. In direct quotations, qualitative data is analyzed as a result of student reflections to certain questions (see italics).

\section{Results}

\subsection{Demographics}

The findings concluded with $1804(23.42 \%)$ of the 7792 students choosing different universities from both sectors i.e., public and private and different majors to participate in the study. Of the enrolled students, 35 percent were graduates (Political Science, Business Administration and Education, Law, Natural Sciences, Public Administration), while 43 percent were undergraduates (Pakistan Studies, Islamyat, Urdu/Sindhi/English, Physical Education, Microbiology), while postgraduates consisted of 22 percent of the sample. The majority (73 percent) of students are recognized as women while 23 percent of sample comprised of male students (Table 1 ).

Table 1: Participants' descriptive characters

\begin{tabular}{|c|c|c|}
\hline Variables & Sample Size N & Percentage (\%) \\
\hline \multicolumn{3}{|l|}{ A. Demographics: Academic Status } \\
\hline Graduates & 631 & 35 \\
\hline Undergraduates & 773 & 43 \\
\hline Postgraduates & 400 & 22 \\
\hline Total & 1804 & $100 \%$ \\
\hline \multicolumn{3}{|l|}{ Gender } \\
\hline Male & 487 & 27 \\
\hline Female & 1312 & 73 \\
\hline Total & 1804 & $100 \%$ \\
\hline \multicolumn{3}{|c|}{ B. Telecommunication: Students used devices at home for online classes/homework } \\
\hline Faculty Computers & 11 & 0.64 \\
\hline Laptop/other & 149 & 8.3 \\
\hline iPad/Tablet & 250 & 13.9 \\
\hline Smartphone & 1389 & 77 \\
\hline Total & 1804 & $100 \%$ \\
\hline \multicolumn{3}{|l|}{ Internet access at home } \\
\hline Broadband & 230 & 12.74 \\
\hline Digital Subscriber Line & 460 & $25 \cdot 50$ \\
\hline Cellular Phones & 874 & 48.44 \\
\hline No Internet access & 235 & 13.02 \\
\hline Total & 1804 & $100 \%$ \\
\hline \multicolumn{3}{|l|}{ C. Job/Work Type } \\
\hline Daily wages & 390 & 21.6 \\
\hline Contractual Work & 567 & 31.4 \\
\hline Permanent & 112 & 6.20 \\
\hline Part Time & 270 & 15 \\
\hline Unemployed & 562 & 31.15 \\
\hline Total & 1804 & $100 \%$ \\
\hline \multicolumn{3}{|c|}{ D. The Internet Facility Provided by University at Home } \\
\hline Did not Use/Access & 1149 & 63.7 \\
\hline Use it & 655 & 36.3 \\
\hline Total & 1804 & $100 \%$ \\
\hline Use more than 3 Hours/Day & $45^{8 / 655}$ & 70 \\
\hline Logging in Successfully (Graduates) & 1036.5 & $57 \cdot 45$ \\
\hline Undergraduates & 667.5 & 36.93 \\
\hline Postgraduates & 100 & $5 \cdot 54$ \\
\hline Total & 1804 & $100 \%$ \\
\hline \multicolumn{3}{|c|}{ E. Students' Online Teaching Style Preferences: Asynchronous vs. Synchronous } \\
\hline Asynchronous & 1425 & 78.9 \\
\hline Synchronous & 379 & 21.1 \\
\hline
\end{tabular}


Percentage (\%)

F. Students' Academic tasks

Additional Academic tasks 1380

424 76.5

Same Academic tasks (No Increase)

23.5

G. Teaching Faculty Routines: Faculty Provided the Adjusted Syllabi before

Transition to Online Classes

\begin{tabular}{|c|c|c|}
\hline Yes & 974 & 53.9 \\
\hline No & 830 & 46.1 \\
\hline Availability of Faculty in their offices during online Classes & 216 & 11.7 \\
\hline Faculty Communication & 361 & 20 \\
\hline Availability of Recorded Lessons/material & 794 & 44 \\
\hline \multicolumn{3}{|l|}{ H. Students' Motivation to Learn } \\
\hline Motivated & 812 & 45 \\
\hline Difficult to be Motivated & 992 & 55 \\
\hline Remembered to Login to Online Classes & 920 & 50 \\
\hline Online Quizzes & 920 & 51 \\
\hline Communicate with each other & 1398 & $77 \cdot 5$ \\
\hline Creating Time for Online Tasks & 920 & 51.1 \\
\hline \multicolumn{3}{|l|}{ I. Social and Financial Impacts } \\
\hline Concerned about Infected with Virus & 1263 & 70 \\
\hline Concerned about the Health of Family/Close Friends & 1443 & 80.1 \\
\hline \multicolumn{3}{|l|}{ Virus has had Financial Impact } \\
\hline Yes & 956 & 53.4 \\
\hline No & 848 & 46.6 \\
\hline Lost their Jobs & 963 & 53.4 \\
\hline Working at Slowed Business Area & 541 & 29.9 \\
\hline \multicolumn{3}{|l|}{ Change in Working Hours } \\
\hline Yes & 469 & 26 \\
\hline No & 1334 & 74 \\
\hline Working for Longer Hours & 211 & 11.7 \\
\hline Change in Daily Life & 1028 & 56.8 \\
\hline Caretaking Responsibilities & 277 & 15.4 \\
\hline Overall Change in Life & 1010 & 56 \\
\hline
\end{tabular}

\subsection{Telecommunication}

Students indicated they have various devices when asked whether they used the internet at home for academic work. According to Table 1, only o.64 percent of all students have faculty computers, 8.3 percent have a laptop/other, 77 percent have smart phones, and 13.9 percent had an iPad or tablet. In terms of home online access, 12.74 percent of students sought Broadband internet, 25.50 percent sought Digital Subscriber Line (DSL), and 48.44 percent sought help through their phones. Only 13.02 percent of students did not have access to the internet at home. Although universities gave students web areas of interest to use at home, 63.7 percent of students could not access or use them. 70.2 percent of undergraduates (out of 655) who had access to the internet at home used it for three hours or more each day. Despite the fact that $63.07 \%$ of undergraduates and $20 \%$ of graduates were unsuccessful or only partially successful in signing up for online classes. The asynchronous style of teaching was preferred by the majority of the students (78.9 percent). Not being able to manage specialized concerns $(n=198)$, and adaptability in online class planning were among the reasons they provided $(n=147)$ and 100 reactions, etc, and the way that they could learn at their speed.

Student's response:

"Because my internet connection is unreliable, I'm unable to access the Internet. Unfortunately, my Zong $4 G$ device is frequently unreliable. The situation is the same as in the previous example. This version of Net is incompatible with my package. As a result, my mobile hotspots don't function very well. It is impossible for me to miss anything now that I have recorded the lectures that I can watch at my leisure. Because I have multiple opportunities to listen to pre-recorded lectures, I enjoy doing so. Whenever I am unsure, I take notes or look up information. This allows me to watch them at my own pace, as they are less intrusive and can be viewed when they are most useful. So I'm able to plan other aspects of my life with this tool!" (An Undergraduate student) 


\subsection{Students' preferences on Web-based Instruction}

Asked why they preferred synchronous classes, students $(n=381)$ listed everything from their ability to connect with teachers and peers (221 reflections) to the fact that they were less likely to skip classes (12 reflections). They also cited the fact that synchronous classes help them stay aware of lectures, provide structure and persuade and hold them accountable $(n=382)$.

One of them said:

"My learning is enhanced by being able to communicate with my instructor during the online class. A question or concern about the subject can be discussed right away with my educator, rather than having to wait and hope they will get to it or understand what I am saying. When compared to classroom teaching, asynchronous teaching does not allow for the same level of interaction or exploration. My motivation to complete the project has increased as a result. It's more organized, but I'd be more relaxed if I could watch lectures at my leisure. According to students ( $n=205$ ) who were asked why they preferred one style of online class over the other, both styles worked equally well, they concluded". (A graduate student)

\subsection{University Students' Academic tasks during Pandemic}

Web-based courses have increased the academic tasks for the majority of students ( $76.5 \%)$, as shown in Table 1. Computer composing notes $(46.8 \%)$ and discussion penal $(22.2 \%)$ were the two most common types of appraisals assigned. There was no increase in the course academic tasks for the remaining students $(23 \cdot 5 \%)$.

\subsection{Teaching Routines}

With regard to teaching faculty routines, $53.9 \%$ of students revealed that they (faculty) provided the adjusted syllabi of the courses before the transition of web-based teaching, while $46.1 \%$ provided a changed course prospectus prior to the completion of online courses for the remainder of the academic year of $2020-2021$ sessions. Around $20 \%$ of students claimed faculty talked to them about what to expect from online classes, but only 3.4 percent indicated they didn't. According to the students who took part in the study, 44.3 percent of teaching faculty provided instruction in online sessions, 11.7 percent were available in their offices throughout the transition to online classes, and 44 percent put their recorded talks on the LMS (Table 1).

\subsection{Motivation to Learn}

Whereas in the fall 2020 semester, most (65 percent) respondents have online classes that they are able to remain convinced and complete their tasks on time, regardless of the challenges of the unexpected change. Only 35 percent of students felt it was difficult to stay motivated to learn. A slight majority of the students 50 percent polled made sure to sign in to complete scheduled quizzes online, and 77.5 percent had the opportunity to confer with their classmates on a number of course assignments. Only 51.1 percent of students said they had the choice to save time so they could focus on and finish their studies.

\subsection{Social and Financial Effect}

Table 1 online classes that $70 \%$ of students were concerned that the infection of COVID-19, whereas $24.7 \%$ and $05.3 \%$ were modestly or surprisingly concerned that the infection is occurring. Despite this, the majority of students $(80.1 \%)$ were concerned about the health of family and close friends due to Coronavirus. Students have suffered financial losses as a result of the Coronavirus. 53.4\% of students reported they had lost their jobs as a result of the Coronavirus. Fulltime teaching faculty 
accounted for $10 \%$ of the total, while $29.9 \%$ claimed they were working in regions where business had slowed. The global trade rate circumstances were one area in which an international student demonstrated that Coronavirus had been monetized. The student stated, "As an international student, the online classes have altered my financial security." Another problem brought up by a graduate student was the lack of income from the participation property. Almost $61 \%$ of students said the Coronavirus had a financial impact on them. $26 \%$ had changed their working hours, $11,9 \%$ maintained the same hours and yet different schedules were given, $24,4 \%$ required more hours and $33,8 \%$ did not change at all. Changes or obligations in the working environment were mentioned in the comments:

"I'm an education specialist, so I'm exhausted as of now." "As so many people are leaving my job, I'm currently working on over time. Seven days, I'm working for six days; including 11-hour shifts in three days." "I'm fortunate enough to have the option to keep at home."

Because of Coronavirus, majority of the undergraduates', graduates' and postgraduates' taking care of responsibilities have changed,--15.4 percent had to take care of a child, and $29 \%$ had to take care of a sickly loved one. In general, $56.8 \%$ of students said the pandemic had a significant influence on their daily life, 35.9 percent said it had a moderate impact, and 5.2 percent said it had no impact.

\subsection{Students' Perceptions about Distance Education}

While the shift of traditional classes to distance education which was unplanned, quick, and uncertain, many students have learned to use of the internet and other devices and how to get benefit of learning from this situation, they have reported certain effects. Over $46 \%$ of students $(n=830)$ said they didn't face as much difficulty as it was perceived, hence they saved money. They said:

"I don't have to come to campus," they continued, "which would take up around two hours out of my day on a regular basis." "I won't have to wait an hour for university points." "I don't have to drive or pay for gas or fuel charges right now."

Other benefits mentioned included students having more time to work on activities and spend time with loved ones $(n=292)$

"There's additional time and chances for me to complete tasks now that my classes are taught online."

A number of students were aware of how to handle their time (899 reactions).

"I think some teachers have online classes real flexibility and a strong desire to help our class to keep things as simple and easy as they can,"

And some have adaptability and can therefore supervise courses at their own speed (417 reactions). Just a little level of students (10o reactions) announced no sure outcomes.

\subsection{Undergraduates, Graduates and Postgraduates' Suggestions}

In order to develop further the distance-learning experience, which has been grouped in twelve themes, the students reacted on 165 perceptional statements: 1) improve teaching faculty accessibility, communication, teaching (more engaging), and care (211 reflections); 2) response properly the circumstances, be merciful with scores and grading, and acknowledge the understand students' needs, (101 reflections); 3) application of tailored assessments and academic tasks (201 reflections); 4) showing satisfaction with their efforts, well done (51 reflections); 5 ) telecommunication, availability and access to required devices, application software, and the internet (250 reflections); 6) resourceful 
and trained teaching faculty provisions for all (200 reflections); 7) provisions of manageable tuition fees structure (90 reflections); 8) digital libraries on demand (110 reflections); 9) national or international seminars on corona and other diseases (216 reflections); 10) scholarships and financial benefits (100 reflections); 11) access to digital libraries (174 reflections); and 12) availability of laptops and other devices for students (10o reflections).

\section{Descriptive and Inferential Analysis}

The independent variables of this study are: 1) social and financial factors, 2) teaching faculty routines, 3) academic tasks, and 4) telecommunication, while 1) motivation to learn, 2) job related factor, 3) online teaching style preferences, and 4) study related academic tasks are the dependent variables. In addition, "how COVID-19 affecting graduates and postgraduates academic life" is chosen as the key independent variable in our multivariate design, and "motivation to learn and completion of academic tasks on time" are the major dependent variable. To study the relationship between independent and dependent variables, researcher applied a linear regression analysis. Researcher set alpha $=0.001$ as a significance level of all the motivation to learn variables, ("How have you communicated with your class fellows in group assignments?", "Do you remember to log in to take online tests/quizzes?" "Have you completed your assignments on time?", "How do you create to do you online assignments and projects?") "Motivation to learn and completion of academic tasks on time" had the statistically significant two dimensional relationship with the COVID-19 social and financial variable "how COVID-19 affecting graduates and postgraduates academic life?"); $\beta=0.176, p$-value $=$ o.014. Table 2 online classes these relationships.

Table 2: Correlation analysis of social and financial factors, teaching faculty routines, academic tasks, and telecommunication vs. motivation to learn

\begin{tabular}{|c|c|c|c|}
\hline Variables & $\begin{array}{l}\text { Regression } \\
\text { Coefficient }\end{array}$ & $P$ value & $\begin{array}{l}\text { 99\% Confidence } \\
\text { Interval }\end{array}$ \\
\hline \multicolumn{4}{|l|}{ Job-related Factors } \\
\hline COVID-19 affecting your financial security & 0.184 & 0.084 & 0.021 to -0.021 \\
\hline Your concerns about getting COVID-19 & -0.002 & 0.184 & 0.015 to -0.032 \\
\hline $\begin{array}{l}\text { Your concerns about the health of family or close friends because of COVID-19 } \\
\text { Overall }\end{array}$ & -0.021 & -0.822 & 0.019 to -0.012 \\
\hline COVID-19 affecting day to day life, overall & -0.008 & 0.021 & 0.093 to -0.028 \\
\hline COVID-19 affecting academic life & 0.202 & 0.121 & 0.043 to -0.031 \\
\hline \multicolumn{4}{|l|}{ Taking Care of } \\
\hline Taking Care of a child when childcare/school is closed & -0.003 & 0.221 & 0.011 to -0.021 \\
\hline Taking Care of ailing beloved & 0.210 & 0.098 & 0.013 to -0.011 \\
\hline \multicolumn{4}{|l|}{ Social and Financial Factors } \\
\hline Have you lost your job/slowed down your business? & 0.329 & -0821 & 0.073 to -0.061 \\
\hline Have your work hours changed due to the COVID-19 outbreak? & -0.002 & 0.498 & -0.047 to -0.022 \\
\hline \multicolumn{4}{|l|}{ Teaching Faculty Routines } \\
\hline Availability of Faculty during office hours for online classes & 0.230 & $<0.01$ & 0.023 to -0.081 \\
\hline The engaging way of Faculty while conducting online classes & 0.3421 & $<0.01$ & 0.047 to -0.023 \\
\hline $\begin{array}{l}\text { Availability of an adjusted online syllabus before the beginning } \\
\text { of the online classes by Faculty }\end{array}$ & 0.376 & $<0.01$ & 0.013 to -0.031 \\
\hline Faculty communication what with regards to online classes & 0.421 & $<0.01$ & 0.013 to -0.023 \\
\hline Availability of recorded lectures & 0.491 & $<0.01$ & 0.041 to -0.027 \\
\hline \multicolumn{4}{|l|}{ Study related Academic tasks } \\
\hline Transitioning to online classes increased academic tasks & 0.217 & 0.076 & 0.049 to -0.024 \\
\hline \multicolumn{4}{|l|}{ Increase in your academic tasks because of Corona } \\
\hline Projects & -0.032 & 0.432 & 0.076 to -0.033 \\
\hline Assignments & -0.076 & 0.876 & 0.098 to -0.061 \\
\hline Portfolio development & -0.054 & 0.443 & 0.033 to -0.065 \\
\hline Out of class activities & -0.032 & 0.076 & 0.046 to -0.073 \\
\hline Quizzes & -0.037 & 0.098 & 0.076 to -0.009 \\
\hline Discussion Panels & -0.033 & 0.421 & 0.089 to -0.062 \\
\hline
\end{tabular}




\begin{tabular}{lccc}
\hline Variables & $\begin{array}{c}\text { Regression } \\
\text { Coefficient }\end{array}$ & $\begin{array}{c}\text { P value } \\
\text { Interval }\end{array}$ \\
\hline Tele-communication & & & \\
\hline The internet access at home & 0.654 & 0.543 & 0.098 to -0.098 \\
Digital Subscriber Line & 0.454 & 0.488 & 0.048 to -0.045 \\
Broadband & 0.632 & 0.076 & 0.009 to -0.065 \\
Cellular Phone services & 0.664 & 0.454 & 0.087 to -0.098 \\
Have you access to your university's internet hotspot? & -0.434 & 0.653 & 0.080 to -0.095 \\
How much access do you have? & 0.454 & 0.487 & 0.054 to -0.076 \\
Success rate in logging on to participate in classes online & 0.685 & $<0.001$ & 0.098 to -0.087 \\
\hline Preferences regarding online Teaching Styles & & & \\
\hline Synchronous Instruction VS. Asynchronous & -0.009 & 0.065 & 0.043 to -0.043 \\
\hline Institution Type: Public/Private University & & & \\
\hline Public vs. Private University & 0.322 & 0.098 & 0.098 to -0.002 \\
Fees Structure & 0.984 & 0.495 & 0.092 to -0.098 \\
Courses Offered & -0.409 & 0.609 & 0.044 to -0.034 \\
Internship Provision & 0.676 & 0.054 & 0.061 to -0.071 \\
Help in Publication & 0.698 & 0.452 & 0.001 to -0.071 \\
Health Insurance & 0.632 & 0.098 & 0.051 to -0.001 \\
Exemption/ Promotion Policy & 0.664 & 0.409 & 0.061 to -0.041 \\
\hline
\end{tabular}

Correlational analysis of data did not online class statistically significant relationships between university students' inspiration to complete their study and telecommunication $(p=0.589)$, online teaching style (synchronous/ asynchronous) $(p=0.098)$, and academic tasks $(p=0.209)$. Furthermore, the relationships between university students' inspiration to complete their study and faculty posting of recorded class lectures on the university learning management system $(p=.01)$, Students and faculty are informed about what to expect from online classes $(p=.01)$ prior to the start of online classes, faculty members must provide revised online class syllabi $(p=.01)$, job related factors $(p=.01)$, faculty accessibility for office hours $(p=.01)$, level of education $(p=.01)$, type of institution $(p=.01)$, taking care of factor $(p=.01)$, health insurance $(p=.01)$, Engaging faculty facilitation of online courses $(p=.01)$.

After getting control over variables in the design (See Table 3), with the multivariate linear regression analysis, researcher established that the university students expressed low concern being infected COVID-19, the high the rate of completion their projects and assignments and other tasks within time $(\beta=0.076, p$-value $=0.876)$. Regression analysis also set up that the university students have more chances of getting communicated with teaching faculty during online classes, the higher the rate of completion of projects, assignments and other tasks within time $(\beta=0.642, p$-value $<$ o.0o1). The greater number of successes of university students for logging in for online classes, the higher the rates of completion of projects, assignments and other tasks within time $(\beta=0.236, p$ value $<0.073)$. However, the relationship between converting of classes online and university students' motivation of completing the projects, assignments and other tasks within time $(p=0.823)$. Similarly, researcher did not find any statistically significant relationship between jobs related factor, gender, academic status, and university students' motivation of completing the projects, assignments and other tasks within time.

Table 3: MANOVA of university students' motivation of completing the projects, assignments and other tasks within time and social and financial factor, teaching faculty routines factor, study related academic tasks factor, telecommunication factor, taking care of factor, institution type factor, online teaching styles factor.

\begin{tabular}{lccc}
\hline Variables & $\begin{array}{c}\text { Regression } \\
\text { Coefficient }\end{array}$ & $\begin{array}{c}\text { P value } \\
\text { Social and Financial Factors }\end{array}$ & $\begin{array}{c}\text { 99\%onfidence } \\
\text { Interval }\end{array}$ \\
\hline 1. Your concerns about getting Corona & 0.224 & 0.004 & 0.009 to 0.309 \\
2. Your concerns about health of family or friends during Corona & -0.002 & 0.198 & -0.087 to -0.065 \\
3. Corona: a threat/blessings for your financial security & -0.065 & 0.445 & 0.054 to -0.053
\end{tabular}




\begin{tabular}{|c|c|c|c|}
\hline Variables & $\begin{array}{l}\text { Regression } \\
\text { Coefficient }\end{array}$ & Pvalue & $\begin{array}{l}\text { 99\%Confidence } \\
\text { Interval }\end{array}$ \\
\hline 4. Lost your job or slowed down your own business & -0.009 & 0.089 & -0.076 to -0.098 \\
\hline 5. change in your work hours because of Corona outbreak & 0.207 & 0.109 & 0.065 to -0.009 \\
\hline 6. Taking Care of a child when childcare/school is closed & -0.078 & 0.289 & -0.098 to -0.043 \\
\hline 7. Taking Caring of an ailing loved one & -0.299 & 0.034 & -0.095 to -0.065 \\
\hline \multicolumn{4}{|l|}{ Teaching Faculty Routines } \\
\hline 8. Availability of Faculty during office hours for online classes & -0.298 & $<0.001$ & 0.066 to -0.045 \\
\hline 9. The engaging way of Faculty while conducting online classes & -0.343 & $<0.001$ & 0.043 to -0.036 \\
\hline $\begin{array}{l}\text { 10. Availability of an adjusted online syllabus before the } \\
\text { beginning of the online classes by Faculty }\end{array}$ & -0.399 & $<0.001$ & -0.009 to -0.076 \\
\hline 11. Faculty communication what with regards to online classes & -0.467 & $<0.001$ & -0.066 to -0.021 \\
\hline 12. Availability of recorded lectures & 0.495 & $<0.001$ & 0.009 to -0.076 \\
\hline \multicolumn{4}{|l|}{ Academic tasks } \\
\hline $\begin{array}{l}\text { 13. Increased academic tasks due to transitioning to online classes } \\
\text { Telecommunication }\end{array}$ & 0.209 & 0.090 & -0.065 to -0.003 \\
\hline 14. your access to the internet at home & -0.690 & 0.589 & 0.087 to -0.035 \\
\hline 15. Digital Subscriber Line & 0.487 & 0.434 & -0.032 to -0.065 \\
\hline 16. Broadband & -0.609 & 0.078 & 0.009 to -0.052 \\
\hline 17. Cellular Phones & 0.689 & 0.498 & -0.032 to -0.002 \\
\hline 18. Have you access to your university's internet hotspot? & -0.409 & 0.623 & 0.041 to -0.088 \\
\hline 19. How much access do you have? & 0.445 & 0.456 & 0.009 to -0.094 \\
\hline 20. COVID-19 affecting day to day life, overall & -0.645 & $<0.001$ & -0.065 to -0.034 \\
\hline \multicolumn{4}{|l|}{ Teaching Style Online Preferences of Students } \\
\hline 21. Synchronous Instruction VS. Asynchronous & -0.078 & 0.098 & -0.005 to -0.099 \\
\hline \multicolumn{4}{|l|}{ Demographics } \\
\hline 22. Male vs. Female & -0.489 & 0.643 & 0.065 to -0.024 \\
\hline 23. Freshman vs. Junior & 0.434 & 0.443 & -0.051 to -0.028 \\
\hline 24. Freshman vs. Senior & -0.696 & $<0.001$ & -0.002 to -0.024 \\
\hline 25. Masters vs. Freshman & -0.423 & 0.653 & 0.098 to -0.022 \\
\hline 26. Graduate vs. Freshman & 0.467 & 0.465 & -0.523 to -0.087 \\
\hline 27. PhD vs. Freshman & -0.698 & $<0.001$ & 0.083 to -0.033 \\
\hline 28. M.Phil vs. Freshman & -0.434 & 0.609 & -0.903 to -0.045 \\
\hline
\end{tabular}

\section{Discussion and Conclusion}

Corona virus-19 forced all courses to be moved online. These challenges were examined as well as what teaching faculty should do to help students overcome them. The study also evaluated the positive effects students cited as a result of participating in distance learning online. We'll be teaching all courses online in the academic year of 2020-2021 sessions, due to a corona virus.

\subsection{Telecommunication}

Universities and teaching faculty were worried before the online classes that the students would have problems with online courses because of issues with access to the internet. There were further concerns that this investigation would influence the students' motivation to learn, academic performance, and success in the classes throughout the academic year of 2020-2021 sessions along with various elements. The text is entirely recorded in terms of faculty concerns. Aristovnik et al, (2020), survey showed that the lack of access to the internet of the college students negatively impacted their academic results. The findings of the investigation revealed again that 13 percent (234.5) of the 1804 students surveyed did not access the internet. In any case it does not ensure internet providers' access to a technological device. While universities gave students access to the internet, studies have revealed that many students cannot take interest to visit the Websites. Given the fact that distance education is here to stay, universities should now look into this issue in greater depth, as well as find ways to help students gain reliable online access. Students' well-being is directly related to the future of higher education. 


\subsection{Instruction Preferences and Online Classes}

When it comes to distance education, the large number of students favored asynchronous teaching. Because it allowed them to learn at their own pace and complete assignments and project work when they were ready, this was the obvious choice. Moreover, it was beneficial to access pre-recorded lecture sessions and different resources and worked on their ability to manage their schedule from anywhere at any time. These findings are consistent with the findings of Aristovnik et al., (2020). The majority (43\%) of undergraduate students chose $100 \%$ online (asynchronous) option to classify their favorite method for online teaching. According to Aristovnik et al., (2020), asynchronous learning allows students to access course data, demonstrate what they've learned, and talk with colleagues and faculty without being in the same classroom. Asynchronous teaching style, as per Aristovink, gives non-conventional students adaptability as well as provides distinctive styles of teaching-learning, as students can choose the options for materials and the amount of time to needed for specific class. As an alternative, some students preferred live-streamed lectures and quick feedback on course assignments, as well as faculty-student interaction. This led to better organization of their homework as well as a reminder that they were not to be late with their work. "Synchronous education" has the advantage of unrestricted and dynamic connections, say Rajab and colleagues (Watson, J., 2020). When it came to online teaching, many students liked the combination of synchronous and asynchronous methods.

\subsection{Academic Tasks}

Despite being told that the transition to distance education would result in more academic work, students' motivation to learn and complete academic tasks on time remained unaffected by this information. The students were determined to finish the semester with high grades, despite the many obstacles they faced. It is therefore essential that we modify expectations and reduce assessments and grading policies that overly test online participation and the ability to absorb teaching notes in distance education.

\subsection{Teaching Faculty Routines}

In order to make arrangements for shifting to distance education mode the university administration and teaching faculty engaged in a preliminary activities are carried out for a smooth transition. Results showed that the focus on preparing faculty for resolving student needs in the online classes setting was on informing students about course expectations, having recorded class lectures available, and being available during office hours. Zahra Malik (2020) was of opinion that online classes that students are likely to give very high ratings for teaching faculty, according to them, who facilitate learning, engaging the class, effective in communication, set courses efficiently, apply accurate performance assessment routines, give high value to students learning, and respect their students (Watson, J., 2020).

\subsection{Motivation to Learn}

902 students said they were motivated to learn no matter what. The fact that they completed and turned in their work on time, just as they were logging in for quizzes and lectures, was not surprising. Their motivation can be attributed to their ability to communicate with professors throughout the semester, to access course materials and recorded lectures, and to adjust to the calendar. A goal and a coordinated response, according to Watson, J. (2020), are the driving forces behind motivation. Motivation affects when and how one decides to learn online, according to the researchers (Adnan, 2020). It has been found that motivated students are more likely to take on challenging tasks, perform better and persist longer, be more effectively engaged in learning, adopt a learning approach, 
remember to complete their academic tasks on time even in difficult circumstances (Adnan, 2020).

\subsection{Social and Financial Factors}

Coronavirus was very high of a concern among students (75.7 percent). In terms of money, the pandemic disrupted the majority of the students' (56.1 percent) financial activities. Financial experts predicted that the execution of moderation endeavors around the world to balance Coronavirus 19 tightening grip would hasten job losses and create new schedules. This is exactly what happened to private and public university students (undergraduates, graduates, and postgraduates) who had jobs. A majority of students (57) said the pandemic had a huge impact on their daily lives. Through unified national command (Zahra, 2020), families have been isolated, public spaces have been closed, and financial activity has fundamentally slowed as a result of the remarkable public reaction gauges applied to contain the pandemic, making arrangements for the existences of university students to find a way into the pandemic situation (Adnan, 2020). They also had to deal with the possibility that inflation resulting from global monetary inactivity could result in the cancellation of their scholarships.

\subsection{Distance Education}

When the university closed and students were still adjusting to the new world of online classes, there was a general consensus that they would no longer collaborate with teaching faculty or companions. In most cases, students do not take only online courses in a particular semester. Many students, according to the results of the study, were fine with not being physically present with their teachers as long as they had access to courses, materials, and tests. Some of the positive comments mentioned for the justification were less effective, more time to carry out tasks, time efficiency and participation in energy with the family. Other benefits mentioned included having more time to rest, increased communication with a teaching faculty, and learning to adjust to deadlines. The findings of efficiently managing time were unanticipated.

\section{Suggestions}

Asked what universities, administration, and faculty can do to improve distance education experiences, students offered a variety of suggestions. Analyzing student suggestions, the following ten themes emerged: i) provision of sustainable and accessible ICT (ii) application of a tailored grading and assessment policy; (iii) trained and resourceful teaching faculty for prompt response and communication; (iv) adjusted academic tasks; (v) prepare teaching faculty for web-based teaching; (vi) making engaging content for asynchronous classes; (vii) adjusted fees structure; (viii) support in research paper publication; (ix) provision of health insurance; and (x) provision of more internship options. It will be discarded suggestions that did not improve their experience, while those that did will be reported and repeated in the future. Dynamic, student-centered educational experiences result in more profound education, says a researcher.

\section{A General Conclusion}

Despite the extraordinary circumstances that forced students to complete the academic year 20202021 via distance education, students remained motivated to learn and complete their assessments and tasks on time. In light of the sudden and unexpected changes that affected teaching faculty, motivation, and readiness for distance education, students' suggestions to university administration and teaching faculty have been reported. 


\section{Limitations}

One of the limitations of the study is that nearly only 23 percent of the student sample took part in the study. While the data support the efforts of students, that teaching faculty and university administration to facilitate effective, significant instructional methods in this emergency, it would have been preferable to have no less than 33 percent of the student sample. Furthermore, the study is limited in so far as the students' emotional levels may have affected their understanding of the effect of the online transition in exceptional cases.

\section{References}

Aristovnik A, Keržič D, Ravšelj D, Tomaževič N, Umek L (2020). Impacts of the COVID-19 pandemic on a life of higher education students: a global perspective. Sustain; 12(20):1-34. Doi: 10.3390/su12208438

Adnan M. (2020). Online education amid the COVID-19 pandemic: student's perspectives. J Pedagogy Soc Psychol; 1(2):45-51. doi:10.33902/jpsp.2020261309

Ahmad, I., Ur Rehman, K., Ali, A., Khan, I., \& Khan, F. A. (2014). Critical Analysis of the Problems of Education in Pakistan: Possible Solutions. International Journal of Evaluation and Research in Education (IJERE), 3(2), 79-84. https://doi.org/10.11591/ijere.v3i2.1805

Asad, S., Habib, M., Karachiwalla, N., Kosec, K., Leaver, C., \& Ur Rehman, A. (2020). Improving teacher accountability in Pakistan's rural universities. International Growth Centre. https://www.theigc.org/blog/improving-teacheraccountability-in-pakistans-rural-universities/

ASER Pakistan. (2019). Annual Status of Education Report.

Basic Education Coalition. (2020). Pivot Stories: BEC Members Continue to Meet New Learner Needs during COVID-19. Basic Education Coalition.

Batada, A., Banerjee, S., Subramanian, M., Banerjee, S., \& Subramanian, M. (2016). Opening New Doors: Community Engagement in X. In The Sesame Effect: The Global Impact of the Longest Street in the World (pp. 207-229). Routledge. https://doi.org/10.4324/9781315751399-22

Bensaid B, Brahimi T. (2020). Coping with COVID-19: higher education in the GCC sectors i.e., public and private. RII Forum Athens; 72:1-19.

Bennardo F, Buffone C, Fortunato L, Giudice A. (2020). COVID-19 is a cclassroomenge for dental education-a commentary. Eur J Dent Educ;24(4):822-824. doi:10.1111/eje.12555

Biswas A, Bhattacharjee U, Chakrabarti AK, Tewari DN, Banu H, Dutta. (2020). The emergence of Novel Coronavirus and COVID-19: whether to stay or die out? Crit Rev Microbiol. (2020) 46:182-93. DOI: 10.1080/1040841X.2020.1739001

Burns, M. (2020). School, interrupted: 4 options for distance education to continue teaching during COVID-19. Global Partnership for Education. https://www.globalpartnership.org/blog/school-interrupted-4-optionsdistance-education-continue-teaching-during-covid-19

Carol L. (2020). The Coronavirus Pandemic Has Revealed How Fragile Everyday Life Is. Available online at: https://theconversation.com/the-corona virus-pandemic-has-revealed-how-fragile-everyday-life-is-134637

Coman C, Țîru LG, Meseșan-Schmitz L, Stanciu C, Bulgaria MC. (2020). Online teaching and education in higher education during the coronavirus pandemic: students' perspective. Sustain. 12(24):10367. doi:10.339o/su122410367

Chowdhury, Z., Islam, R., \& Saltmarsh, S.-J. (2020). How BRAC is supporting Bangladesh to continue education in a pandemic. http://blog.brac.net/how-bangladesh-is-continuing-education-in-a-pandemic/

DePietro A. (2020). Here's a Look at the Impact of the Corona virus (COVID-19) on Higher education institutions and Universities in the U.S. Available online at: https://www.forbes.com/sites/andrewdepietro/2020/o4/30/impactcorona virus-covid-19-higher education institutions-universities/\#6ecab23661a6

DevTrio Consultants. (2019). Research into Digital Accessibility and Literacy among School Teachers in Punjab: Research Report. British Council. https://www.britishcouncil.pk/sites/default/files/dal_compressed_22_august_2019.pdf

Elzainy A, El Sadik A, Al Abdulmonem W. (2020). Experience of e-education and online assessment during the COVID-19 pandemic at the University of Medicine, Qassim University. J Taibah Univ Med Sci ;15(6):456-462. doi:10.1016/j.jtumed.2020.09.005

Fasih, T., Baron, J., \& Geven, K. M. (2019). Pakistan: Education Poverty Brief. EduAnalytics. http://pubdocs.worldbank.org/en/214101571223451727/SAS-SACPK-PAK-LPBRIEF.pdf 
Friedman J. Tackle Challenges of Online Classes Due to COVID-19. (2020). Available online at: https://www.usnews.com/education/best-higher education institutions/articles/how-to-overcomechallenges-of-online-classes-due-to-corona virus

Government of Pakistan. (n.d.). Ministry of Federal Education and Professional Learning. Retrieved August 11, 2020, from http://www.mofept.gov.pk/Detail/ODJIMmMyYTktN2QxYyooY2YoLWIwYjYtZmYxMDNIYmRkNmQw

Government of Pakistan. (2018). Pakistan Education Statistics (2016-17). http://library.aepam.edu.pk/Books/Pakistan\%2oEducation\%2oStatistics\%202016-17.pdf

Government of Pakistan. (2020). Pakistan Social E Living Standards Measurement Survey (2018-19). Pakistan Bureau of Statistics.

Hares, S., \& Mundy, K. (2020). Equity-Focused Accesses to Education Loss during COVID-19. https://www.cgdev.org/blog/equity-focused-accesses-education-loss-during-covid-19

Hasan N, Bao Y. (2002). Impact of e-Education crack-up perception on psychological distress among university students during COVID-19 pandemic: a mediating role of fear of academic year loss. Child Youth Serv Rev; 118:105355. doi:10.1016/j.childyouth.2020.10535512

Iqbal, N. (2020, August 11). EDUCATION-PAKISTAN: ALIF Spells Open Sesame For Pre-schoolers | Inter Press Service. Inter Press Service News Agency. http://www.ipsnews.net/200o/o4/education-pakistan-alif-spellsopen-sesame-for-pre-schoolers/

Jeffrey, R., Oberlander, J., MacDonald, S., \& Bhatti, F. (2016). Digital Citizenship in Pakistan. British Council. https://www.britishcouncil.pk/sites/default/files/digital_citizenship_in_pakistan.pdf

Khalil R, Mansour AE, and Fadda WA. (2020). The sudden transition to synchronized online education during the COVID-19 pandemic in Saudi Arabia: a qualitative study exploring medical students' perspectives. BMC Med Educ. 2020;20(1). doi:10.1186/s12909-020-02208-z

Li, C., \& Lalani, F. (2020). The COVID-19 pandemic has changed education forever. This is how. World Economic Forum. https://www.researcherforum.org/agenda/2020/04/corona virus-education-global-covid19-onlinedigital-education/

Lee YN. (2020). 7 Charts Online class How the Coronavirus Pandemic Has Hit the Global Economy. Available online at: https://www.cnbc.com/2020/04/24/corona virus-pandemics-impact-on-the-global-economy-in-7charts.html

McAleavy, T., \& Gorgen, K. (2020). What does the research suggest is best practice in pedagogy for distance teaching?

McBurnie, C. (2020). The use of virtual education environments and education management systems during the COVID-19 pandemic (EdTech Hub Helpdesk Request No. 7). EdTech Hub. https://doi.org/10.5281/zenodo.3805843

Ministry of Education and Federal Learning (Pakistan). (2020). National Education Response and Resilience Plan for COVID-19. http://mofept.gov.pk/SiteImage/Misc/files/o_\%2oNERRP\%2oCOVID-19\%2oMoFEPT\%204 \%20May\%202020\%20Ver\%2001.pdf

Ministry of IT \& Telecom (Pakistan). (2018). Digital Pakistan Policy. https://www.moitt.gov.pk/SiteImage/Misc/files/DIGITAL\%2oPAKISTAN\%2oPOLICY.pdf

Naz, S., Memon, A., ul Haque, M., Nadeem, U., Jamal, G., \& Khan, A. (2016). Pakistan District Education Rankings. https://d3n8a8pro7vhmx.cloudfront.net/alifailaan/pages/537/attachments/original/1474368820/Pakistan_Di strict_Education_Rankings_2016_Full_Report.pdf?1474368820

Okeleke, K. (2019). The Poresearcherr of Mobile to Accelerate Digital Transformation in Pakistan. GSMA. https://www.gsma.com/mobilefordevelopment/wp-content/uploads/2020/o6/The-Poresearcherr-of-

Mobile-to-Accelerate-Digital-Transformation-in-Pakistan-2019.pdf

Ramos-Morcillo AJ, Leal-Costa C, Moral-García JE, Ruzafa-Martínez M. (2020). Experiences of nursing students during the abrupt change from face-to-face to e-Education education during the first month of confinement due to COVID-19 in Spain. Int J Environ Res Public Health; 17(15):5519. doi:10.339o/ijerph17155519

Rajab MH, Gazal AM, Alkattan K. (2020). Challenges to Online Medical Education During the COVID-19 Pandemic. Cureus; 12(7):8966. doi:10.7759/cureus.8966

Sangwan, S. (2020). Coronavirus: Edtech unicorn BYJU'S free offer sees a 150\% jump in new students. https://yourstory.com/2020/o4/edtech-unicorn-byjus-students-free-access-corona virus

Schwab, K. (2019). The Global Competitiveness Report. World Economic Forum.

Simonson GAB. Distance Education Education. Britannica: Encyclopedia Britannica, Inc. (2016).

Sydow, L. (2020). Mobile Minute: Global Sessions Rely on Education Apps As Distance Education Accelerates. App Annie. https://www.appannie.com/en/insights/mobile-minute/education-apps-grow-distance-education-corona virus/

Trach E. (2018). Asynchronous Education: Definition, Benefits, and Example Activities. Available online at: https://www.schoology.com/blog/asynchronous-education-definition-benefits-and-example-activities \#: :text=Asynchronous\%2oeducation\%2oallows\%2oflexibility\%2ofor,dive\%2ointo\%2oa\%2ogiven\%2otopic 
UNESCO. (2020). Distance education solutions. https://en.unesco.org/covid19/educationresponse/solutions

UNESCO, UNICEF, World Bank, \& World Food Programme. (2020). Framework for reopening universities. https://unesdoc.unesco.org/ark:/48223/pfoooo373348/PDF/373348eng.pdf.multi

USAID. (2020). Delivering Distance Education in Emergencies: A Review of Evidence and Best Practice.

Watson, J. (2020, March 31). Education through television in low-income contexts: mitigating the impact of coronavirus (COVID-19). EdTech Hub. https://doi.org/10.5281/zenodo.470780o

Watson, J., \& McIntyre, N. (2020). Educational Television: A Rapid Evidence Review (Rapid Evidence Review No. 5; EdTech Hub Rapid Evidence Review). EdTech Hub. https://doi.org/10.5281/zenodo.4556935

Williamson K, Given LM, Scifleet P. (2018). Qualitative Data Analysis. 2nd ed. Elsevier Inc; doi:10.1016/B978-o-o8102220-7.00019-4

World Health Organization (202). Corona virus Disease (COVID-19) Situation Report - 128. Available online at: https://www.who.int/docs/default-source/coronaviruse/situation-reports/20200527-covid-19-sitrep128.pdf?sfvrsn=11720coa_2

World Health Organization (2020). Coronavirus disease (COVID-19). Coronavirus disease (COVID-19); https://www.who.int/emergencies/diseases/novel-corona virus-2019.

Worldometer.org (2021, July 21). https://www.worldometers.info/coronavirus/?fbclid=IwAR3Nlo_X-RKeFZvcZ_EY9ZKsycTG7L-hWlGagZ7ogHf_2zcuqOpOUo-R4M

Zahra-Malik, M. (2020, July 14). The coronavirus effect on Pakistan's digital divide. BBC Worklife. https://www.bbc.com/worklife/article/20200713-the-corona virus-effect-on-Pakistan-digital-divide 